This provisional PDF corresponds to the article as it appeared upon acceptance. A copyedited and fully formatted version will be made available soon. The final version may contain major or minor changes.

\title{
Intramedullary spinal cord tumors: the value of intraoperative neurophysiological monitoring in a series of 57 cases from two Italian Centres.
}

Delia CANNIZZARO, Cristina MANCARELLA, Davide NASI, Maria Pia TROPEANO, Carla Daniela ANANIA, Giovanni CATALETTI, Daniela MILANI, Enrica FAVA, Reza GHADIRPOUR, Francesco COSTA, Franco SERVADEI, Maurizio FORNARI

Journal of Neurosurgical Sciences 2019 Sep 23

DOI: $10.23736 / \mathrm{S} 0390-5616.19 .04758-1$

Article type: Original Article

๑ 2019 EDIZIONI MINERVA MEDICA

Article first published online: September 23, 2019

Manuscript accepted: September 12, 2019

Manuscript revised: August 1, 2019

Manuscript received: May 29, 2019

Subscription: Information about subscribing to Minerva Medica journals is online at: https//www.minervamedica.it/en/how-to-order-joumals.php

Reprints and permissions: For information about reprints and permissions send an email to: joumals.dept@minervamedica.it - joumals2.dept@minervamedica.it-joumals6.dept@minervamedica.it 


\section{Intramedullary spinal cord tumors thevalue of intracperativeneurcphysiological monitoring in a series of 57 cases fromtwo Italian Centres.}

Delia Cannizzaro MD¹, PhD, Cristina Mancarella,MD22 Davide Nas, MD4, Maria Pia Tropeano, $M D^{1}$, Carla Daniela Anania $M D^{1}$, Giovarni Cataletti $M D^{1}$, Daniela Milani $M D^{1}$, Enrica Maria Fava $M D^{5}$, Reza Ghadirpour, $M D^{3}$, Francesco Costa $M D^{1}$, Franco Senvada ${ }^{1}$, Maurizo Fornari $M D^{1}$

1 Department of Neurosurgery, Humenitas Clinical Research Hospita, Neurocenter, Rozzano, Milan, Italy.

2 Department of Neurosurgery, IRCSS, Neuromed, Pozzilli, Italy.

3 Department of Neurosurgery, University Hospital of Pamea and Department of Neurosurgery, Institutefor Scientific and Care Research "ASMN" of Reggio Emilia.

4 Department of Neurosurgery, Unberto I Generd Hospita, Università Politecrica delle Marche, Ancona

5 Neurosurgery, Department of Medical Biotechnology and Transiaional Medicine, Università degli Studi di Milano, Rozzano (MI).

\section{Corresponding Author}

Maria Pia Tropeeno

meriapiatropeeno@libero.it 
Viale Alessandro Manzoni, 56

Rozzano, Milan

Italy

\section{ABSTRACT}

Background Intramedullary spinal cord tumors are rare lesions of the central nervous system Anatomical, molecular and radiological fectures are well defined, but correct management is still matter of debate Petinent litercure has reported conflicting opinions regarding the use of intraoperdive electrophysiological monitoring (IONM) in the surgical treament of this kind of lesions, recently. We report a retrospective study from two Italian centres, in order to highlight the usefuness of IONM in themenagement of intramedullary lesions.

Methods We performed a retrospective review of patients with intramedullary spinal tumor who underwent surgical resection from February 2011 to February 2018 in two different institutions. Clinical and radiological data, lesion fectures, timing of symptom onset and IONM findings were recorded. The IONM induded sometosensory-evoked potentials(SSEP), motor-evoked potentias(MEP) and D-Wave whenever possible We evaluated the outcome according to the Modified McCormick scale. Wealso evaluated the accuracy and relevance of surgical outcomes for each evoked potentia(SSEP, MEP, D-Wave).

Results A total of 57 patients were induded. A gross total removal was achieved in 46 cases. Neurological follow-up was assessment at 3 days, and 3 and 6 months after surgery. Comparing the preoperdive staus and 6 morths follow-up: the M-McCormick scale showed a neurological stability for 30 patients (52.63\%), a worsening of neurological staus for 7 patients (12.28\%) and an improvement for 20 patients (35.08\%). IONM presented high accuracy (sensibility of $100 \%$ and specificity of $95.65 \%)$ and significantly predicted postoperdive permenent motor deficits 
$(\mathrm{P}<0.0001 ; \mathrm{AUC}=0.978)$. D-Wave appered to have significant grecter predictive value than MEP and especially SSEP alone( 0.967 vs 0.722 vs $0.542 ; P=0.044$ and $P \varangle 0.001$ respectively).

Condusions The gold standard in the intramedullary lesion treatment is meximal safe resection with good neurological outcome, as shown in our patients. The use of IONM is helpful in intramedullary turmors resection in order to minimize postoperdive neurological deficits and our analysis suggests that the use of D-Wave presents a staistically significant higher accuracy for predicting postoperdive de icits than SSEP and MEP alone

Keyworcs spinal tumor, intraoperdive monitoring; intramedullary tumors; D-wave, motor evoked potentials; somtosensory evoked potentials. 
Abbreviations

MEPs: Motor evoked potentials

SSEPs: Somtosensory evoked potentials

IONM: Multimodal intraperative monitoring

NCCN: National Comprehensive Nerwork 


\section{Introctuction:}

Intramedulary spinal cord tumors (IMSCT) comprise 2 - $8.5 \%$ of central nevous system neoplasms in adults (1). The most common type of IMSCT is ependymoma followed by astrocytorra (1).

Microsurgical resection with gross-total removal of IMSCT is considered the primery treatment modality, followed by adjuvant radiotherapy, especially for high gradetumors (2).

The surgical option should take into account the risk-benefit ratio due to the high possibility of postoperdive neurological deficits. Despite recent advantages, surgery for IMSCTs is still very challenging and may cary significant morbidity.

Intraoperative neuro-electrophysiological monitoring (IONM) has been shown to play an important role in IMSCT surgery but recently their role has been debated (3-7).

Multimodality IONM includes somatosensory evoked potentials (SSEPS), motor evoked potentials (MEPS), D-waves, and electromyography. D-waves are generated via transcrarial stimulation and monitored directly at the spinal cord level via placement of an epidura/subdural recording edectrode caudal to the region at risk. D-waves are relatively resistant to anesthetic effects and permit the use of neuromusaular blockade for paralysis (8). D-waves can only be used above D10 since its recording is generded in the spinal cord. In generd, a $20 \%$ decreese in D-wave amplitude is considered to be a preliminary waming, whereas a $50 \%$ reduction in amplitude is considered indicative of potential neurological injury. Conbining the use of these multiple IONM modalities could improve dinical outcomes by meximizing surgical manipulations to pathologies while minimizing damegeto normal structures

The purpose of this study was to investigate 1) preoperative dinical staus, turnor fetures and timing of dinical onset as predicting factors in postoperative neurological outcomes, 2) the usefulness of IONM in the menagement of IMSCT, 3) the accuracy of IONM (SSEPS, MEPS, and D-waves) in predicting new postoperdive neurological deficits 


\section{Methods}

\section{Study population}

The authors retrospectively reviewed the surgica/dinical database and 300 cases of spinal tumor were extracted, from which 57 patients affected by spinal intramedullary lesion were selected (Tab

1). The patients were treated by serior spinal surgeons (M.F, F.S., R.G) in two institutions (Hurrenitas Research Hospita, Milan, and Santa Maria Hospita, Reggio Emilia) between February 2011 and February 2018. The two institutions basically shared the same indications for surgery and the same intraoperdive monitoring.

Eligibility criteria included:

-Pre and postoperative imaging accessible,

-Clinica/demographicfollow-up dataavailable

-Complete histo-pathological and molecula information

-Use of intraoperdivemonitoring during thesurgical removal procedure

Exclusion criteria

-I ncompleteradiologica/dinica//demographic/follow-up data

-Metatasis;

-Caudaequine ependymoma

Informed consent was signed before each surgical procedure in according to IBC gidelines.

Preoperdive-dinical and radiological data 
A careful neurological dinical examination was pefformed in the preoperdive phase An MRI was peformed with and without gadolinium to define characteristics of the tumors and idertify any multiple locations if present. We reviewed the preoperdive imeges to calcul ate the diamere, length and volume of the lesion, to consider any possible association between preoperaive clinical status and lesion characteristics. Moreover, we reported the time between the onset of symptoms and surgical treatment.

\section{Surgical managenent}

All patients underwert a dedicated anesthetic protocol for interventions with IONM including orotrached intubation without pancuronium and induction of anesthesia with propofol and remifentanil without halogenated anesthetics. Anesthesia was then maintained with propofol (100$150 \mathrm{~g} / \mathrm{kg} / \mathrm{min}$ ) and fentanyl ( $1 \mathrm{~g} / \mathrm{kg} / \mathrm{hr}$ ) infusions, avoiding bolus doses. This protocol minimizes the interaction of drugs with IONM and facilitates a rapid awakening with the possibility of early neurological assessment. Sphinteric function was monitored in cases of lesions involving the lower thoracic cord. Patients were placed in prone position. A Mayfiedd damp was used for cervica surgeries A standard laminectomy was pefformed for al patients. IONM was used. Baseline SSEP and MEP, epidura electrodes were placed above and below the levels of the durotomy to monitor D-Wave, whenever possible Posterior median sulaus was then idertified and gently opened to access the tumbr. Ultrasound examination was useful in some selected cases to confim the position of the tumor (10) as well as an intraperdive imege fusion between intraoperdive CT and preoperative NMR (11).

A myelotomy was performed with continuous electrophysiological monitoring (dorsal colum mapping) to reach the lesion through a safe entry zone We preferred not use coagulation and remained within the limits of the tumor, performing intemal debulking with the help of dissector and tumor forceps, and an ultrasonic surgical aspirctor. (Fig 1) 


\section{Postoperdivedeficit and follow-up}

Clinical/neurological examination was performed immediately after surgery. A postoperdive MRI was performed within 7 days following surgery. The postoperdive modified McCormick Scale (Tab 2) gradewas assigned a day 3 after surgery and at the 3 and 6-month follow-up. We consider improvement of neurological outcome a decreese of almost 1 point in McCormick scale and worsening of neurological outcome an increse of almost 1 point in McCormick scale All changes in IONM were correlated with postoperdive and follow-up neurological staus. All new motor deficits were def ined as permenent or transitory if present or not at 6-month follow-up.

\section{Statistica analysis}

Categorical variables were compared using the di square test. The analysis was pefformed to evaluate key predictors of postoperdivefunctional outcomes.

The Kruska-Wallis $\mathrm{H}$ test, a rank-based nonparametric test, was used to determine if there were stasticaly significant differences between two or more groups of an independent variable on a continuous or ordinal dependent variable

Each IONM modality accuracy was detemined by comparing intraoperdive evoked potential changes to the presence of new persistent motor post-operdive deficits via receiver operding characteristic (ROC) curves. A Pairwise t test was then used to compare the ROC arves of the SEPs, MEPs and D-Wave

\section{Results}

\section{Baseline characteristics}

A total of 57 patients ( $30 \mathrm{M}, 27 \mathrm{~F}$, men age $49.9 \mathrm{yr}$ ) were induded. Results of beseline characteristics including sex, age, predominant spinal level of operation, histology, modified 
McCormick Scale grade on admission and at follow-up, neurophysiological evaluation with SSEPS and MEPs, are summerized in Table 1.

Ependymomes were the most frequent sudtype of tumors with 37 cases $(64.91 \%), 6$ hemangioblatomes (10.52\%), 4 atrocytomes $(7.01 \%$, grade III), 5 cavemous malformation (8.77\%) and 5 other tumors 1 melanocytome (1.75\%), 1 solitary fibrous tumor (1.75\%), 1 granulocytome (1.75\%), 1 mesendymal turnor (1.75\%) and 1 capillary hemengioma $(1.75 \%)$.

The lesion was located in: the cervica spine in 20 cases, the cervico-thoracic spine in 10, the thoracic spine in 25 , the lumbar spine in 1 case, and at the bulbomedullary junction in 1 case (Table 3) An associated syringomielia was present in 12 patients.

Clinical symptoms were nonspecific with, the predominant being: pain (17.54\%), paraparesis (24.56\%), monoparesis $(14.03 \%)$, tetraparesis $(10.53 \%)$, hemiparesis $(12.28 \%)$, bladder dysfundion (7.02\%), ataxia (8.78\%), and sensory deficits (5.26\%). The diagnosis was incidental only for 6 patients but in the wait-and-see period we observed a significant increse in turnor size. The dinical data were dassified in a standardized scale and, atter careful neurological examination, all patients wereevaluated according to the modified McCormick Scale

Preoperdive M-Mc grade was I for 17 patients, II for 18 patents, III for 16 patients, and IV for 6 patients. (Tab 3)

The mean time between signs or symptom onset and surgery was 16.7 months (7 days to 228 months). A gross total removal was obtained in 46 cases (80.70\%) and a subtotal removal in 11 (19.30\%). For those cases the histological diagnosis was: 3 astrocytoma, 5 ependymoma 1 melanocytoma 1 mesenchymal tumor and 1 granuloma The reasons for the subtotal removal were: persistent variations in IONM in 6 cases, intraoperdive histological report in 3 cases and in 2 cases the tumor tissue was not easily dissectible from nervous tissue. For two of these patients the Dwave had not been positioned since the tumor was located in D12.

\section{IONM changes and dinical correlations}

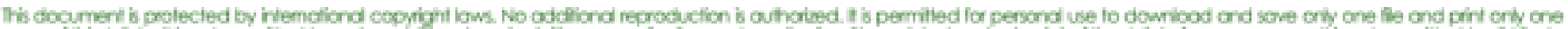

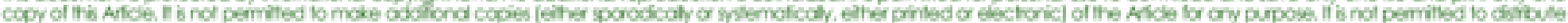

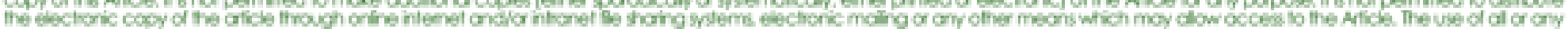

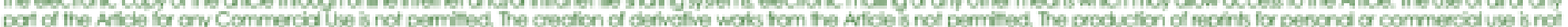

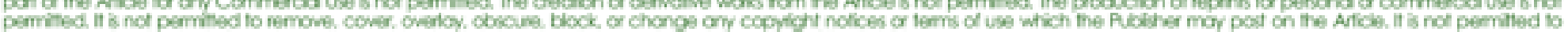

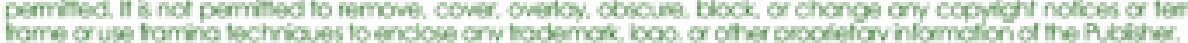


Overdl significant IONM changes were registered in 33 patients out of 57 (57.89\%). In 17 cases (51.51\%), the presence of a stable cauda D-wave was predictive of a favorable long-term motor outcome even when the MEP and/or SEP were reduced or lost and allowed us to proceed with complete tumor resection. To the contrary, in 7 cases (21.21\%) the D-wave amplitude dropped by $50 \%$ ore more and wechose to stop tumor resection due to the high risk of permenent paraplegia In $5 \operatorname{coses}(15.15 \%)$ the D-wave was reduced of less than $50 \%$ at theend of the surgery, al lowing us to complete the procedure In 3 cases $(9.09 \%)$ the D-wave recording resulted difficult and unstable during the surgical procedure and at the end of tumor resection the D-wave was diminished over $50 \%$, while MEP and SSEP remained stable or slightly changed. All of these patients emerged from surgery without any deficit and we considered the results of registration of D-Wave as a false positive Finally, in 1 case (3.03\%) the D-wave was not used because of the lesion site (D12) and we recorded a reduction of SSEPS

Postoperdive complications were observed in 13 patients (22.8\%): 10 cases of CSF leeks, 1 case of CSF leak and meningitis, 1 intramedullary hematoma, 1 venous thrombosis of the legs and meringitis. The CSF leaks were treted with external spind drainage and antibiotic theray in 7 cases, while 4 coses required surgical revision. The meningitis was trected with antibiotic therapy, the intramedullary hemtoma was re-operated, and the venous thrombosis of the legs was tretted withanticoagulant therapy.

Postoperdive 3-day M-Mc gradewas I for 17 patients, II for 14 patients, III for 11 patients, IV for 13 patients, $V$ for 2 patient. At 3-day postoperaiveevaluation, compared to the preoperaive status, 29 patients (50.87\%) remained stable, 9 cases (15.78\%) improved and 19 patients (33.3\%) worsened after the surgical procedure. At 6-month follow-up the M-McCormick scale showed a neurological stability for 30 patients (52.63\%) compared to the preoperdive status, for 7 patients (12.28\%) a worsening of neurological staus and an improvement for 20 patients $(35.08 \%)$ with a dear improvement of the neurological staus as compared to the immediate postoperdive period. (Tab 4) 
Table 2 shows the M-McCormick postoperdiveand during follow-up, in detail.

Statistica analysis of results

Our series showed no significant difference in age $(\mathrm{p}=0.953)$ or $\operatorname{sex}(\mathrm{p}=1.000)$ or the timing of onset of symptoms $(\mathrm{p}=0.681)$ in predicting a good 6 -month outcome The only associated predictor seems to be patient preoperative neurological staus $(\mathrm{P} \varangle 0.001)$.

We analyzed the correlation between preoperdive dinical staus and the diameter of theturror ( $p=$ $0.4951)$, the length $(p=0.5053)$ and the volume $(p=0.1857)$ of the lesion but there was no staistically significant relationship betweentumor size and symptoms.

Sensitivity, specificity, positive predictive value (PPV), negative predictive value (NPV), likel ihood ratio positive (LH+) and likelihood ratio negative (LH-) analysis of ech evoked potential are shown in Table 5.

In our series, multimodal IONM (SSEP+, MEP+, D-wave) presented high accuracy (sersibility of $100 \%$ and specificity of $95.65 \%$ ) and significantly predicted postoperdive permenent motor deficits $(\mathrm{P} \varangle 0.0001 ; \mathrm{AUC}=0.978$ ). Comparing the area under ROC curves (AUC) of these tests, $\mathrm{D}$-Wave appeered to have significant greter predictive valuethan MEP and especially SSEP alone ( 0.967 vs 0.722 vs $0.542 ; \mathrm{P}=0.044$ and $\mathrm{P}<0.001$ respectively). The ROC curves were displayed in Figure 2 and these results weresummaized in Table 5.

\section{Disarsion}

The golden standard of treatment for intramedullary spinal cord tumors should be meximal safe resection avoiding, whenever possible, the worsening of neurological symptoms. This goal can be achieved better if the lesions are trected by an experienced neurosurgeon in a highly specialized center with all thelatest technological tools available. 
Excellent results have been reported in both pediatic and adult patients (12, 13). Additionally, as surgical techniques continue to advance, patient outcome is expected to improve with a decrese in risks associated with resection $(13,14)$.

Postoperdive outcome is determined by many factors. The preoperdive neurological status, the time of postoperdive hospitalization, as well as the time between the onset of symptoms and the surgical procedure, impact on the postoperdive outcome (15)

Our staistical data suggest that the volume, diameter and length of the tumbr do not irfluence the postoperative outcome of patients. It is therefore essential to proceed with the surgical removal of an intramedullary lesion at the onset of symptoms. In accordance with recent litercture, erly surgical intervention (in the presence of symptoms) is recommended since it minimizes the risk of postoperdive complications, thus reducing hospitalization time and improving the dinical outcome of patients $(16,17)$.

The histology of thetumor is another important predictive factor of good outcome

Astrocytomes and ependymomes represent the most common intramedullary neoplasms (18).

Ependymomes usualy require gross tota removal without any postoperdive trement (19).

Early diagnosis and surgery, before severe pardysis, are important to obtain good functional outcomes

Subtotal resection may be necessary in some cases, particularly in patients with encapsulated tumors $(15,20)$. There are no randomized trials addressing the role of postoperative radiation therapy and it appears to offer no advantages over gross total removal (21). Most observational studies have found that postoperdive RT is associated with improved local control and progressionfree survival, but the ffect on overal survival is less der $(15,22)$. There is a proposal that higher doses of RT (50.4 to $54 \mathrm{~Gy}$ ) are more effective than lower doses (20). Nevertheless, consensusbesed guidelines reported by the National Comprehensive Cancer Network (NCCN) suggest postoperdive RT only for patients who have undergone subtotal resection or biopsy of a 
myxopapillary ependymoma In our series, only 5 patients with ependymoma underwent subtota resection. We chose not to pefform any adjuvant therapy and to follow the patients with periodic MRI scans.

Regarding astrocytomes, the best management strdegy remains controversial. Some studies recommend aggressive resection, while others condude that biopsy alone yields a better prognosis $(23,24)$. In general, it is our opinion that the resection of spinal cord atrocytomes should be reserved for selected cases. We trested 4 astrocytomes: 1 underwent gross total removal and 3 subtotal.

We dinically and radiologicaly followed these patients up to 12 morths following the surgical procedure All of themunderwent adjusant radiotherapy, and none of them had a recurrence

The value of IONM

The use of intraoperdive electrophysiology techniques including SSEP, MEP, D-wave and dorsa column mepping have been advocated to modify surgical strategy, in order to preserve the patient's neurological function after surgery that, along with excision of the entire tumor, is the aim in most procedures $(25,26)$.

As surgical removal, with possible GTR, represents the standard of care in the menagement of these tumors, different tools are described in litercture for this purpose Ultrasonography hejps to determineturmor margins (10), the presence of cysts and the location of theturmor, another option is represented by the use of intraoperdive fluorescein $(27,28)$ and /or intraoperdive navigation by merging CT scan and MRI . (11)

The results of our study suggest that the most important tool for this kind of surgery is the use of IONM. The aim of neurophysiological intraoperdive monitoring is to identify a spinal cord injury at a reversible stage and to modify surgical strategy according to that data Loss of MEPs and/or a decrese in the D-wave amplitude should be a waming to thesurgeon of a motor pathway injury. 
Together with SSEPS, MEPs may totally disappear during surgery. In these cases, if the D-wave amplitude is either stable or decreesed by less than $50 \%$, the possible postoperdive motor deficits will recover after surgery in a few days or months, as shown in our cases. Wehad an intraperdive reduction of the D-wave $<50 \%$ with an important reduction or disapperance of the MEPs in 5 cases and those patients had a transient deficit. Seven patients had a permenent neurological deficit with reduction of the D-wave $\geq 50 \%$. The D-wave has more specificity and sensibility in detecting motor deficit (29) compared to MEPs. This phenomenon can be due to the reversible inativation of noncorticospinal descending tracts and the propriospinal system whiltt fast-conducting corticospinal fibers are mostly preserved (29). Use of dorsal column mapping is essential becausea delicate myelotomy incision is required to reach intramedullary tumors. (Fig 1) The midline in a normal cord is the dorsal median sulcus, located between the elevated posterior columns, midway between the root entry zones. The midline can also be identified by following the dorsal median sulcal vein. However, in the presence of intramedullary tumors the surface antomy may be altered significantly, from cord edema or the turnor itself, and the use of dorsal column mepping becomes necessary in locating a safe entry zone Many symptoms such as generalized numbness, painful dysesthesias below the surgical leve, proprioceptive loss, and gait dysfunction are due to dorsal column dysfunction. These deficits can be very disabling, even with good postoperative motor function. It was possible to reduce the surgical morbidity in IMSCT surgery through the combined use of somztosensory evoked potertial, motor evoked potential, and D-wave recordings (30-32).

\section{IONM accuracy in the IMSCT surgery}

D-Wave monitoring is actualy considered the golden standard for assessing the integrity of CT in spinal monitoring, the real accuracy of D-Wave in comparison with the other evoked potentials is not well investigated (33-36). 
In our study, compaing the area under ROC arves (AUC) of each evoked potential, D-Wave appecred to have grecter predictive value than MEP and especially SEP. (Figure 2)

Based on these results, the recording of D-Wave significantly increased the accuracy of neurophysiological monitoring in intramedulary tumors (34) and also in extramedullary tumors (37).

After more than 10 years of experience in the tredment of intramedullary tumors with IONM these are our remarks:

- often, during surgery, the MEPs response is recorded in an on-off fashion; on the contrary, D-wave deteriordion usually occurs gradually so there is time to takecorrective meesures $(29,30)$.

the D-wave allows a continuous monitoring of the function of the cortico-spinal tract without the need to intemupt surgery for elicitaion of the MEPS, this real-time continuous monitoring is important mostly during dissection of a tumor with less well-defined border between lesion and heat thy spinal cord tissue $(33,34)$.

- A stable D-Wave amplitude allows proceeding with tumor resection even in the case of MEP/SSEP loss because the de ficit expected is transitory (34).

Despite our positive experience, there are still controversial views about the usefulness of IONM during intramedullary spinal cord tumors surgery.

The authors of a recent American Guideline (35) recommended the use of IONM during spinal cord/spinal column surgery only as a diagnostic adjunct to assess spinal cord integrity (level I), while the use of the same moritoring is not recommended as a therapeutic tool during intramedullary turnor resection procedures (level II) or other spinal cord/spinal column surgery (levd III). Finally, the authors concluded that IONM can only document a neurological deficit but does not prevent it and, for this reson, the use of IONM during spinal surgery cannot beconsidered a "standard of care." (36) 
These guidelines have been developed also with the purpose (fully acceptable) of protection from medico-legal complaints based on the "mandatory" use of a technique with limited evidence.

A recent review (38) also failed to show benefit from IONM in spinal tumors surgery but out 15 examined papers only 2 reported the recording of the D-wave which in our experience is the most important monitoring tool.

Many letters were written in response to these guidelines $(47,33)$. Furthermore, other important reviews reached different condusions $(36,39)$. This make us aware that the effectiveness of the IONM is still a debated question and a worldwideconsensus is fa off.

It is our opinion that the use of IONM in defining the correct myelotomy point is undoultedly useful. (Fig 1) Moreover, even if the IONM cannot prevent neurological damege, they can wam the surgeon in order to prevent further surgical menipulation of a sensitive or already injured anatomical region.

This waming is useful in the dinical outcome only if thesurgeon takes care of it (40).

\section{Limits}

The limitations of our study indude its retrospective nature, lack of randomization, and no comparison patient group who underwent tumor removal without IONM. Howeve, monitoring was peformed by the same term throughout the study, and al operations were performed by senior surgeons (M.F, R.G. and F.S.), thus limiting a possible source of bias. Hence, the results of this study may warmant larger prospective studies on a multicenter basis to further elucidate its diagnostic and therapeutic value and cost-ffectiveness in patient care involving IMST.

\section{Condusion:}

Our case series of intramedullary tumors leads us to condude that these tumors should be treeted whenever the patient becomes symptomatic. The probability of a good dinical outcome is dosely 
related to the patient's preoperative neurological status and to the timing between the onset of symptoms and surgical treament while there is no significant redaionship with volume, length or diameter of the tumor. The gold standard should be meximal safe tumor resection. The use of $D$ wave presented staistically significant higher accuracy to predicting postoperdive deficits than SSEP and MEP alone Furthermore, the use of multimodal IONM, induding D-Wave, represents an important tool to avoid neurological injury during surgery, allowing a modification of the surgical strategy and subsequent prevention or mitigation of postoperative deficits.

DeliaCannizzaroandCristinaMancarella cortributed equally to the drafting of this manuscript.

\section{References}

[1] McCormick PC, Torres R, Post KD, Stein BM. Intramedullary ependymoma of the spinal cord.J Neurosurg 1990;72:523-32. doi:10.3171/jns.1990.72.4.0523.

[2] ZouY, Sun J, Zhou Y, Bai HX, Huang X, Babu R, Landi A, Foong KS, Zhang Z, WooJH, Tao Y, Li X, Tang X, Xiao B, Zhang PJ, Yang L. Prognostic Factors and Treatment of Spinal Astrocytomes A Multi-institutional Cohort Analysis. Spine (Phila Pa 1976). 2018 May 15;43(10):E565-E573. doi: 10.1097/BRS.0000000000002485.

[3] Nas D, Ghadimpour R, Servade F. Letter: Guidelines for the Use of Electrophysiological Monitoring for Surgery of the Humen Spinal Column and Spinal Cord. Neurosurgery. 2019 Feb 1;84(2):E127-E128 Sala F, Skinner SA, ArleJE, Constantini S, Deletis V, Kothbaver KF, MacDonald DB, Shils J, Soto F, Szelenyi A. Letter. Guidelines for the use of Electrophysiological Monitoring for 
Surgery of the Hurnen Spinal Colum and Spinal Cord. Neurosurgery. 2018 Aug 1;83(2):E82-E84. doi: 10.1093/neuros/nyy231.

[5] Ney JP, van der Goes DN. Letter. Guidelines for the Use of Electrophysiological Monitoring for Surgery of the Humen Spinal Colum and Spinal Cord. Neurosurgery. 2018 Aug 1;83(2):E78-E79. doi: 10.1093/neurosinyy206 Wilkinson M, Houlden D. Letter: Guidelines for the Use of Electrophysiological Monitoring for Surgery of the Humen Spinal Column and Spinal Cord. Neurosurgery. 2018 Aug 1;83(2):E74E75. doi: 10.1093/neurosinyy157.

[7] Vogel R, Bazer], Getsch], Holdefer RN, LeGR, Moreira J], Wilent B, Shils]L. Letter. Guidelines for the Use of Electrophysiological Monitoring for Surgery of the Humen Spinal Colum and Spina Cord. Neurosurgery. 2018 Jun 1;82(6):E190-E191. doi: 10.1093/neuros/nyy093.

[8] Deletis V, Sala F: Intraoperative neurophysiological monitoring of the spinal cord during spinal cord and spine surgery: a review focus on the corticospinal tracts. ClinNeurophysiol 119:248-264, 2008

[9] Constantini S, Houten J, Miller DC, Freed D, Ozek MM, Rorke LB, \& a. Irtramedullary spinal cord turnors in children under the age of 3 years. J Neurosurg 1996;85:1036-43. doi:10.3171/jns.1996.85.6.1036.

[10] Haciyakupoglu E, Yunnuk E, Onen MR, Naderi S. The Use of Intraoperdive Ultrasonography in Intradura Spinal Tumor Surgery. Turk Neurosurg. 2019;29(2):237-241. doi: 10.5137/1019-5149.JTN.23296-18.3.

[11] Costa F, Ortolina A, Cardia A, Riva M, Revay M, Pecchioli G, Anania CD, Asteggiano F, Fomari M. Preoperdive Magnetic Resonance and Intraoperdive Computed Tomography Fusion for Red-Time Neuronavigation in Intramedullary Lesion Surgery (Oper Neurosurg (Hagerstown). 2017 Apr 1;13(2):188-195...) 
[12] Epstein F, Epstein N. Surgical trestment of spinal cord astrocytomes of childhood. J Neurosurg 1982;57:685-9. doi:10.3171/jns.1982.57.5.0685.

[13] Epstein FJ, Famer JP, Freed D. Adult intramedullary spinal cord ependymomes: the result of surgery in 38 patients. J Neurosurg 1993;79.204-9. doi:10.3171/jns.1993.79.2.0204.

[14] Zileli M, Coșkun E, Ozdamar N, Ovül I, Tunçbay E, Oner K, et al. Surgery of intramedullary spinal cord tumors. Eur SpineJ 1996;5:243-50.

[15] Montano N1, Papacci F2, Trevisi G2, Fenandez E2. Factors affecting functional outcome in patients with intramedullary spinal cord tumors: results from a literdure analysis. Acta Neurol Belg. 2017 Mar,117(1):277-282. doi: 10.1007/s13760-016-06844. Epub2016Jul 30.

[16] Imegame S, Ito Z, Ando K, Kobayasti K, Hida T, Ito K, et a. Optimal Timing of Surgery for Intramedullary Cavemous Hermengiome of the Spinal Cord in Relation to Preoperdive Motor Paresis, Disease Durdion, and Tumor Volume and Location. Glob Spine J 2017;7:246-53. doi:10.1177/2192568217707938.

[17] Raco A, Esposito V, Lenzi J, Piccirilli M, Defini R, Cantore G. Long-term follow-up of intramedullary spinal cord tumors: A series of 202 cases. Neurosurgery 2005;56:972-9. doi:10.1227/01.NEU.0000158318.66568.CC.

[18] Parsa AT, Chi JH, Acosta FL, Ames CP, McCormick PC. Intramedullary spinal cord tumors. molecular insights and surgical innovation. ClinNeurosurg 2005;52:76-84.

[19] Hamilton KR, Le SS, Urquhart JC, Jonker BP . A systematic review of outcome in intramedullary ependymoma and astrocytoma J Clin Neurosa. 2019 May;63:168-175. doi: 10.1016].jocn.2019.02.001. Epub2019 Mar 2.

[20] Weber DC, Wang Y, Miller R, Villà S, Zaucha R, Pica A, \& a. Long-term outcome of patients with spinal myxopapillaryependymome trement results from the MD Anderson Cancer Center and institutions from the Rare Cancer Network. Neuro Oncol 2015;17:588-95. doi:10.1093/nevonc/now293. 
[21] Le S-H, Chung CK, Kim CH, Y oon SH, Hyun S, KimK-J, et al. with or without adjuvant radiation therapy for treatment of spinal ependymoma : a Spinal Oncology Research Group. Neuro Oncol 2013;15:921-9. doi:10.1093/neuonc/not038.

[22] Pica A, Miller R, Villà S, Kadish SP, Anacak $Y$, Abusaris $\mathrm{H}$, et al. The results of surgery, with or without radiotherapy, for primary spinal myxopapillaryependymoma: a retrospective study from the rare cancer network. Irt J RadiatOncolBiolPhys 2009;74:1114-20. doi:10.1016/j.jijrobp.2008.09.034.

[23] Karikar IO, Nimje SM, Hodges TR, Cutrel E, Hughes BD, Powers C], \& a. Impact of tumor histology on resectability and neurological outcome in primery intramedullary spinal cord tumors. A singlecenter experience with 102 patients. Neurosurgery 2015;76:188-97. doi:10.1227/NEU.06013e3181fe3794.

[24] Abd-El-Barr MM, Huang KT, Chi JH. Infiltraing spinal cord astrocytomes: Epidemiology, diagnosis, treatments and future directions. J ClinNeurosci 2016;29:15-20. doi:10.1016/j.jocn.2015.10.048.

[25] Deletis V. Intraperdive neurophysiology and methodologies used to monitor the functiona integrity of the motor system NeurophysiolNeurosurg A Mod. 2002:25-54. doi:10.1016/B978012209036-3/500044.

[26] Yanni DS, Ulkatan S, Deletis V, Barreneche日 IJ, Sen C, Perin NI. Utility of neurophysiological moritoring using dorsal colum mepping in intramedullary spinal cord surgery. J Neurosurg Spine 2010;12:623-8. doi:10.3171/2010.1SPI NE09112.

[27] Ivanov M, Budu A, Sims-Williams H, Poeta I. Using Intraoperdive Ultrasonography for Spinal Cord Tumor Surgery. World Neurosurg 2017;97:104-11. doi:10.1016/j.wneu.2016.09.097. Acerbi F, Cavallo C, Schebesch KM, Akçakaya MO, de Laurentis C, Hamemcioglu MK Fluorescein-Guided Resection of Irtramedullary Spinal Cord Tumors: Results froma Preliminary, 
Multicentric, Retrospective Study. World Neurosurg. 2017 Dec;108:603-609. doi: 10.1016/..wneu.2017.09.061. Epub2017 Sep 19.

[29] Costa P, Peretta P, Faccari G. Relevance of intraoperdive D wave in spine and spinal cord surgeries. Eur SpineJ 2013;22:840-8. doi:10.1007/s00586-012-2576-5.

[30] Simon M V., Chiappa KH, Borges LF. Phase reversd of somtosensory evoked potertials triggered by grailis tract stimulation: A New technique for neurophysiologic dorsal colum mapping. Neurosurgery 2011;3:783-8. doi:10.1227/NEU.0b013e31822e0a76.

[31] Nair D, Kumeraswamy VM, Braver D, Kilbride RD, Borges LF, Simon M V. Dorsal colum mepping via phase reversal method: The refined technique and dinical applications. Neurosurgery 2014;74:437-46. doi:10.1227/NEU.0000000000000287.

[32] Menta AI, Mohrhaus C a Husain AM, Karikari IO, Hughes B, Hodges T, et al. Dorsal column mepping for intramedullary spinal cord tumor resection decreeses dorsal colum dysfunction. J Spinal Disord Tech 2012;25:205-9. doi:10.1097/BSD.0b013e318215953f.

[33] Nas D, Ghadimpour R, Servade F. Intraoperdive neurophysiologic monitoring in spinal intraduralextramedullary tumors: only a prognostic tool? Neurosurg Rev. 2017;40:583-585.

[34] Sala F, Palandri G, Basso E, Larteri P, Deletis V, Faccioli F, et al: Motor evoked potential monitoring improves outcome after surgery for intramedullary spinal cord tumors a histori- cal control study. Neurosurgery 58:1129-1143, 2006

[35] Mark N. Hadley, Christopher D. Shank, Curtis J. Rozzelle Guidelines for the Use of Electrophysiological Monitoring for Surgery of the Humen Spinal Colum and Spina Cord. Neurosurgery. 2017 Nov 1;81(5):713-732

[36] Park J, Le S, Kim E, Eoh W. Analysis of Multimodal Irtraoperdive Monitoring During Intramedullary Spina Ependimoma Surgery 
[37] Ghadirpour R, Nasi D, Iaccarino C, Romeno A, Motti L, Sabadini R, ValzaniaF, Servade F. Intraoperdiveneurophysiological monitoring for intradurdextramedullary spinal tumors: predictive value and relevance of D-wave amplitude on surgical outcome during a 10-yeer experience J Neurosurg Spine 2018 Nov 9;30(2):259-267. doi: 10.3171/2018.7.SPINE18278.

[38] Rijs K, Klimek M, Scheltens-de Boer M, Bieshemel K, Hahangi BS. Intraoperdive Neuromonitoring in Patients with I rtramedullary Spinal Cord Tumor: A Systematic Review, MetaAnalysis, and Case Series. World Neurosurg. 2019 Jan 17. pii: S1878-8750(19)30068-3. doi: 10.1016/].wneu.2019.01.007.

[39] Daniel JW, Boteho RV, Milano JB, Dantas FR, Onishi F], Neto ER, Betolini EF et a. Intraoperdive Neurophysiological Monitoring in Spine Surgery: A Systematic Review and MetaAnalysis. Spine(Phila Pa 1976). 2018 Aug:43(16):1154-1160

[40] Hare R, Schleifer D, Appel S, Attia M, Cohen ZR, Knoller N. Spinal intradurdextramedullary turmors: the value of intraoperdive neurophysiologic monitoring on surgical outcome Neurosurg Rev. 2017 Oct;40(4):613-619. doi: 10.1007/s10143-017-0815-2. Epub2017 Jan 27.

Figure legends

Figure $1 \mathrm{~A}, \mathrm{~B}$ and C show intraperdive monitoring in order to define the entry zone and the myelotomy. Preoperdive cervical MRI, (D) axial and (E) sagittal imeges show a big cervical intramedullary lesion.

Figure 2 The ROC curve compares the accuracy of diagnostic tests. In our analysis, it shows that D-Wave apperred to have significant greter predictive value than MEP and SSEP alone.

Tables 


\begin{tabular}{|c|c|c|c|c|c|c|c|c|c|c|c|c|c|c|c|}
\hline \multirow{3}{*}{$\begin{array}{l}\mathbf{N} \\
\\
\mathbf{1}\end{array}$} & \multirow{3}{*}{\begin{tabular}{l|} 
Ag: \\
55
\end{tabular}} & \multirow{3}{*}{$\begin{array}{l}\text { Sox } \\
M\end{array}$} & \multirow{3}{*}{$\begin{array}{c}\text { Site } \\
\text { D2-D3 }\end{array}$} & \multirow{3}{*}{$\begin{array}{c}\text { Histology } \\
\begin{array}{c}\text { hemangodfoto } \\
\text { ma }\end{array}\end{array}$} & \multirow{3}{*}{$\frac{\text { Syrirx }}{}$} & \multirow{3}{*}{$\begin{array}{c}\text { Romoval } \\
\text { total }\end{array}$} & \multirow{3}{*}{$\begin{array}{c}\text { Complication } \\
\text { intramedular } \\
\text { hemorrage }\end{array}$} & \multirow{3}{*}{\begin{tabular}{|l|}
$\begin{array}{l}\text { Timing } \\
\text { from } \\
\text { diagnosis } \\
\text { (monthe) }\end{array}$ \\
3
\end{tabular}} & \multirow{3}{*}{$\begin{array}{c}\text { MMC } \\
\text { atore } \\
\text { sarpy } \\
11\end{array}$} & \multicolumn{3}{|c|}{ MMC Postop } & \multirow{3}{*}{\begin{tabular}{|c|}
$\begin{array}{c}\text { SSEP } \\
\text { dranges }\end{array}$ \\
$\mathrm{N}$ \\
\end{tabular}} & \multirow{3}{*}{$\begin{array}{c}\text { MEP } \\
\text { changs } \\
Y\end{array}$} & \multirow{3}{*}{$\begin{array}{c}\begin{array}{l}\text { D-Wavy } \\
\text { change }\end{array} \\
Y\end{array}$} \\
\hline & & & & & & & & & & 3 daps & $3 \mathrm{man}$ & 6mate & & & \\
\hline & & & & & & & & & & IV & IV & IV & & & \\
\hline 2 & S1 & $M$ & D5-D7 & ependynuma & $Y$ & subtota & $\mathrm{N}$ & 48 & III & IV & IV & III & $\mathrm{N}$ & $Y$ & $\bar{Y}$ \\
\hline 3 & 35 & $M$ & D4 & cpondymom & $\bar{Y}$ & tota & $\mathrm{N}$ & 3 & 1 & 1 & 1 & 1 & $\mathrm{~N}$ & $\mathrm{~N}$ & $\mathrm{~N}$ \\
\hline 4 & 37 & M & $\begin{array}{l}\text { D11- } \\
\text { D12 }\end{array}$ & ependymoma & $\mathrm{N}$ & tota & N & 6 & 1 & 1 & 1 & 1 & $\mathrm{~N}$ & $\mathrm{~N}$ & N/A \\
\hline 5 & 52 & M & CS & $\begin{array}{l}\text { Cavernous } \\
\text { angioma }\end{array}$ & $\mathrm{N}$ & tota & N & 12 & 1 & 1 & 1 & 1 & $\mathrm{~N}$ & $N$ & $\mathrm{~N}$ \\
\hline 6 & 51 & $F$ & 06 & Cavernome & $\mathrm{N}$ & tota & $\mathrm{N}$ & 6 & III & III & II & III & $\mathrm{N}$ & $Y$ & $\mathrm{~N}$ \\
\hline 7 & 46 & $M$ & $\begin{array}{l}\text { D11- } \\
\text { D12 }\end{array}$ & ependymoma & $\mathrm{N}$ & subtotal & $\mathrm{N}$ & 2 & 1 & 1 & 1 & 1 & $\mathbf{N}$ & $\mathbf{N}$ & N/A \\
\hline 8 & 47 & $M$ & $\mathrm{D} 2$ & $\begin{array}{c}\text { Solitary fibras } \\
\text { tumor }\end{array}$ & $\mathrm{N}$ & total & $\mathrm{N}$ & 30 & II & II & ॥ & 1 & $\mathrm{~N}$ & $\mathrm{~N}$ & $\mathrm{~N}$ \\
\hline 9 & 55 & $M$ & D3-D4 & astrocytarti & $\mathrm{N}$ & subota & CSF-lexk & 14 & $T$ & $T$ & $T$ & $T$ & $\mathrm{~N}$ & $\mathrm{~N}$ & $\mathrm{~N}$ \\
\hline 10 & 17 & $\mathbf{F}$ & $\mathrm{C} 3 \mathrm{CS}$ & $\begin{array}{c}\text { hemangodato } \\
\text { ma }\end{array}$ & $\mathrm{N}$ & tota & CSF-leak & 3 & III & II & II & II & $Y$ & $\mathrm{~N}$ & $\mathrm{~N}$ \\
\hline 11 & 49 & $M$ & $\mathrm{CACS}$ & ependynume & $\mathrm{N}$ & toda & $\mathrm{N}$ & 3 & $T$ & 1 & $T$ & $T$ & $N$ & $\mathrm{~N}$ & $N$ \\
\hline 12 & 59 & $F$ & C7.DI & epencymoma & $\mathrm{N}$ & toda & N & 6 & II & III & III & iा & $\mathrm{Y}$ & $\mathrm{N}$ & $N$ \\
\hline 13 & 74 & $M$ & DQ-D9 & $\begin{array}{c}\text { Capilary } \\
\text { hemangioms }\end{array}$ & $\mathrm{N}$ & total & N & 4 & IV & III & III & III & $\mathrm{N}$ & $\mathrm{N}$ & $\mathrm{N}$ \\
\hline 14 & 51 & $F$ & CAC6 & ependymuma & $\mathrm{N}$ & tota & CSF-lesk & 3 & 1 & II & $T$ & $T$ & $\mathrm{~N}$ & $Y$ & $\mathrm{~N}$ \\
\hline 15 & 62 & $M$ & $\mathrm{C}-\mathrm{C} 7$ & ependynume & $\mathbb{N}$ & tota & CSF-lexk & 10 & $\pi$ & $\pi$ & $\pi$ & $\pi$ & $\mathrm{Y}$ & $\bar{N}$ & $\mathbb{N}$ \\
\hline 16 & 41 & $F$ & C6.D2 & cpendymum & $\mathrm{N}$ & toda & $N$ & 4 & II & III & $\pi$ & iI & 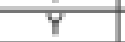 & $\mathrm{N}$ & $N$ \\
\hline 17 & 43 & M & $\mathrm{CBC7}$ & ependyrroma & $\mathrm{N}$ & subtotal & $\begin{array}{c}\text { CSF } \\
\text { lexk/menirgit } \\
\text { is }\end{array}$ & 9 & II & II & II & 1 & $\mathbf{N}$ & $\mathbf{N}$ & $\mathrm{N}$ \\
\hline 18 & 30 & $F$ & D4 & ependynuma & $\mathrm{N}$ & tota & $N$ & 1 & 1 & $T$ & $T$ & 1 & $\bar{Y}$ & $\mathrm{~N}$ & $\mathrm{~N}$ \\
\hline 19 & 48 & $F$ & C7-D1 & cpondymom & $Y$ & tota & CSF-lok & 36 & II & II & II & II & $\mathrm{N}$ & $\mathrm{N}$ & $\mathrm{N}$ \\
\hline 20 & 21 & $F$ & $\begin{array}{l}\text { D12- } \\
\text { L1 }\end{array}$ & ependymume & $\mathrm{N}$ & tota & Whent & 12 & II & II & II & II & $\mathrm{N}$ & $\mathrm{N}$ & N/A \\
\hline 21 & 51 & $\mathbf{F}$ & $\begin{array}{l}\text { DB- } \\
\text { D10 }\end{array}$ & ganulorre & $\mathrm{N}$ & subtotal & N & 24 & IV & IV & IV & IV & $\mathrm{N}$ & $Y$ & $Y$ \\
\hline 22 & 28 & $F$ & $\mathrm{CS}-\mathrm{C7}$ & ependymoma & $\mathrm{N}$ & tota & $\mathrm{N}$ & 2 & 1 & 1 & 1 & $T$ & $\mathrm{~N}$ & $\mathrm{~N}$ & $\mathrm{~N}$ \\
\hline 23 & 56 & $M$ & C7-D3 & cpendymome & $Y$ & tota & CSF-look & 36 & III & III & 11 & II & $\mathrm{N}$ & $Y$ & $Y$ \\
\hline 24 & 70 & $M$ & C3.D4 & ependyrroma & $\mathrm{N}$ & Tota & CSF-leak & 36 & IV & III & IV & IV & $\mathrm{N}$ & $\mathrm{Y}$ & $\bar{Y}$ \\
\hline 25 & 48 & $F$ & $\mathrm{C} 2-\mathrm{CA}$ & $\begin{array}{c}\text { hemangodato } \\
\text { ma }\end{array}$ & $Y$ & total & $\mathrm{N}$ & 101 & II & II & II & II & $\mathrm{N}$ & $N$ & $\mathrm{~N}$ \\
\hline 26 & 54 & $F$ & $\mathrm{C}-\mathrm{CS}$ & ependymoma & $\mathrm{N}$ & tota & $\mathrm{N}$ & 11 & II & 1 & 1 & $T$ & $\mathrm{~N}$ & $\mathrm{~N}$ & $\mathrm{~N}$ \\
\hline 27 & 46 & $M$ & D1-D2 & astrocytome & $\mathrm{N}$ & tota & $\mathrm{N}$ & 2 & II & II & II & 1 & $\mathrm{~N}$ & $Y$ & $Y$ \\
\hline 28 & 43 & $F$ & $\mathrm{CSC7}$ & ependymuma & $Y$ & $\operatorname{tot} d$ & $N$ & 3 & 1 & II & II & 1 & $\mathrm{~N}$ & $\mathbf{N}$ & $\mathrm{N}$ \\
\hline 29 & 50 & $F$ & C4-D2 & ependymoma & $\mathrm{N}$ & tota & $\mathrm{N}$ & 228 & III & II & II & II & $\mathbf{N}$ & $Y$ & $\mathrm{~N}$ \\
\hline 30 & 52 & $F$ & 0306 & ependymoma & $\mathrm{N}$ & tota & CSF-lexk & 84 & II & IV & III & III & $\bar{Y}$ & $\bar{Y}$ & $\bar{Y}$ \\
\hline 31 & 52 & $M$ & 07 & cpendynume & $\bar{Y}$ & tota & $\mathrm{N}$ & 0.25 & III & V & IV & IV & $\mathrm{N}$ & $\bar{Y}$ & $\bar{Y}$ \\
\hline 32 & 56 & $\mathrm{~F}$ & C7-D1 & ependynume & $\mathrm{N}$ & tota & N & 3 & 1 & $T$ & 1 & 1 & $\mathrm{~N}$ & $\mathrm{~N}$ & N \\
\hline 33 & 18 & $M$ & $\begin{array}{l}\text { D9 } \\
\text { D11 }\end{array}$ & ependymuma & $Y$ & tota & $\mathrm{N}$ & 7 & 1 & 1 & 1 & 1 & $\mathrm{~N}$ & $N$ & $\mathrm{~N}$ \\
\hline 34 & 38 & $\mathbf{F}$ & $\begin{array}{l}\text { D10- } \\
\text { D12 }\end{array}$ & astrocytame & $\mathrm{N}$ & subtota & $\mathrm{N}$ & 2 & III & III & III & III & $Y$ & $\mathrm{~N}$ & N/A \\
\hline 35 & 52 & $M$ & 09 & ependymure & $\mathrm{N}$ & tota & $\mathrm{N}$ & 12 & IV & V & IV & IV & $Y$ & $Y$ & $Y$ \\
\hline 36 & 67 & $M$ & $\mathrm{C} 3 \mathrm{CS}$ & cpendymuma & $\mathrm{N}$ & tota & $\mathrm{N}$ & 10 & 1 & 1 & 1 & 1 & $\mathrm{~N}$ & $\mathrm{~N}$ & $\mathrm{~N}$ \\
\hline 37 & 49 & $M$ & D11 & melanocitome & $\mathrm{N}$ & subtota & meningtisfor & 6 & II & IV & IV & IV & $Y$ & $Y$ & $Y$ \\
\hline 38 & 67 & $M$ & C7-D1 & astrocytom & $\mathrm{N}$ & subtota & $\mathrm{N}$ & 4 & 1 & 1 & 1 & 1 & $\mathrm{~N}$ & $\mathrm{~N}$ & $\mathrm{~N}$ \\
\hline 39 & 79 & $\mathrm{~F}$ & 0305 & mesenchymel & $\mathrm{N}$ & subtotal & $\mathrm{N}$ & 1 & III & IV & IV & IV & $\mathrm{N}$ & $Y$ & $Y$ \\
\hline 40 & 31 & $F$ & $\mathrm{CAC5}$ & cpendymom & $\mathrm{N}$ & tota & $\mathrm{N}$ & 3 & 1 & III & 11 & II & $Y$ & $Y$ & $\mathrm{~N}$ \\
\hline 41 & 35 & $\mathbf{F}$ & $\mathrm{C4}+\mathrm{C6}$ & $\begin{array}{c}\text { hemangiodałto } \\
\text { ma }\end{array}$ & $\mathrm{N}$ & total & csf-lok & 5 & 1 & 1 & 1 & 1 & $\mathrm{~N}$ & $\mathrm{~N}$ & $\mathrm{~N}$ \\
\hline 42 & 49 & $M$ & D1-D2 & $\begin{array}{l}\text { Cavonous } \\
\text { horrengiome }\end{array}$ & $\mathrm{N}$ & totai & $\mathrm{N}$ & 2 & II & III & II & II & $\mathrm{Y}$ & $Y$ & $Y$ \\
\hline 43 & 47 & $F$ & modila & epencymoma & $\mathrm{N}$ & twa & $\mathrm{N}$ & 60 & TII & TV & IIII & TII & $\mathrm{Y}$ & Y & $\mathrm{Y}$ \\
\hline 44 & 74 & $F$ & D2 & ependymoma & $\mathrm{N}$ & tota & $\mathrm{N}$ & 10 & IV & IV & IV & IV & $\mathrm{N}$ & $\mathrm{N}$ & $\mathrm{N}$ \\
\hline 45 & 60 & $M$ & $C A C S$ & ependymura & $\mathrm{N}$ & tota & $\mathrm{N}$ & 5 & IV & IV & III & II & $\mathrm{N}$ & $\mathrm{N}$ & $\mathrm{N}$ \\
\hline 46 & 77 & $M$ & C5-D1 & ependymom & $\mathrm{N}$ & subtota & CSF-lak & 18 & III & IV & IV & IV & $Y$ & $Y$ & $Y$ \\
\hline 47 & 36 & $M$ & D3.D5 & ependymoma & $\bar{Y}$ & tota & $\mathrm{N}$ & 4 & III & IV & III & III & $\bar{Y}$ & $\bar{Y}$ & $\mathrm{~N}$ \\
\hline 48 & 65 & $M$ & D4-D7 & ependymoma & $\mathrm{N}$ & tota & $\mathrm{N}$ & 4 & II & II & 1 & 1 & $\mathrm{~N}$ & $\mathrm{~N}$ & $\mathrm{~N}$ \\
\hline 49 & 52 & $M$ & $\begin{array}{l}\text { D7- } \\
\text { D11 }\end{array}$ & ependyrrume & $\mathrm{N}$ & totad & $\mathrm{N}$ & 6 & III & III & II & II & $Y$ & $Y$ & $\mathrm{~N}$ \\
\hline
\end{tabular}




\begin{tabular}{|c|c|c|c|c|c|c|c|c|c|c|c|c|c|c|c|}
\hline & & & & angoma & & & & & & & & & & & \\
\hline 54 & 24 & $M$ & C4.C7 & ependymuma & $\bar{Y}$ & tota & $\mathrm{N}$ & 6 & II & III & $\pi$ & $T$ & $\bar{Y}$ & $\bar{Y}$ & $\mathrm{~N}$ \\
\hline 55 & 56 & $M$ & C6-D1 & $\begin{array}{c}\text { hemengodasto } \\
\text { ma }\end{array}$ & $\mathrm{N}$ & tota & N & 9 & III & IV & III & II & $\mathrm{N}$ & $Y$ & N \\
\hline 56 & 65 & $F$ & $06 \mathrm{C7}$ & ependymume & $\mathrm{N}$ & tota & $\mathrm{N}$ & 7 & $T$ & $T$ & $T$ & $T$ & $\mathrm{~N}$ & $N$ & $\mathbb{N}$ \\
\hline 57 & 66 & $\mathbf{F}$ & D7 & $\begin{array}{c}\text { herrangodato } \\
\text { ma }\end{array}$ & N & total & N & 2 & III & II & II & 1 & $Y$ & $Y$ & N \\
\hline
\end{tabular}

Table 1 Clinical and radiological datasumery

\begin{tabular}{|l|l|}
\hline Grade & Modified McCormick scale \\
\hline I & Intact neurologically, nomal deambulation, minimal dysesthesia \\
\hline II & Mild motor or sensory deficit, functional independence \\
\hline III & Moderatedeficit, limitation of function, independent withexterna aid \\
\hline IV & Severe motor or sensory deficit, limited function, dependent \\
\hline V & Paraplegia or quadriplegia even with flickering moverent \\
\hline
\end{tabular}

Table 2 Modified McCormick scale

\begin{tabular}{|c|c|}
\hline N & 57 \\
\hline Gender (M) & $30(52.6 \%)$ \\
(F) & $27(47.4 \%)$ \\
\hline Age(years) & $49.9 \pm 14.1$ \\
\hline
\end{tabular}




\begin{tabular}{|c|c|}
\hline Predominant spinal level of operation & \\
\hline Cervical & $20(35.1 \%)$ \\
\hline Cervico-thoraic & $10(17.5 \%)$ \\
\hline Thoracic & $25(43.9 \%)$ \\
\hline Lumbar & $1(1.75 \%)$ \\
\hline Bulbomedulary junction & $1(1.75 \%)$ \\
\hline Histology & \\
\hline Ependymoma & $37(64.9 \%)$ \\
\hline Hermengioblastoma & $6(10.5 \%)$ \\
\hline Cavemous melformetion & $5(8.8 \%)$ \\
\hline Astrocytoma & $4(7.0 \%)$ \\
\hline Melanocytoma & $1(1.75 \%)$ \\
\hline Solitary fibrous tumor & $1(1.75 \%)$ \\
\hline Granulocytoma & $1(1.75 \%)$ \\
\hline Mesenchymel turmor & $1(1.75 \%)$ \\
\hline Capillary hemengiome & $1(1.75 \%)$ \\
\hline Mocified MoCormick scale grade & \\
\hline At admission & \\
\hline $\mathrm{T}$ & $17(29.8 \%)$ \\
\hline II & $18(31.6 \%)$ \\
\hline
\end{tabular}

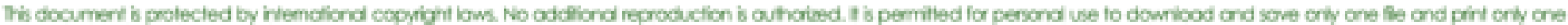

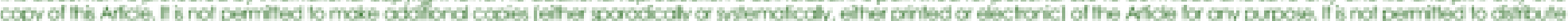

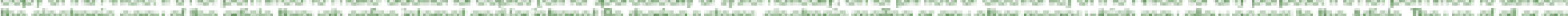

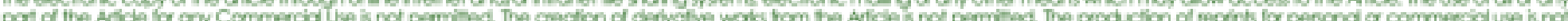

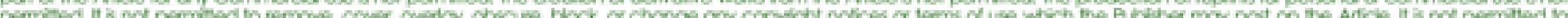

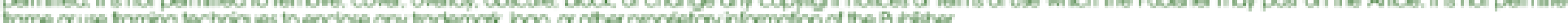

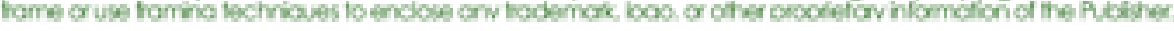




\begin{tabular}{|l|c|}
\hline III & $16(28.1 \%)$ \\
\hline IV & $6(10.5 \%)$ \\
\hline
\end{tabular}

Table 3 Histology, localization, clinical and neurological data

\begin{tabular}{|l|c|}
\hline N & 57 \\
\hline Modified McCormick scale grade & \\
\hline 3 daysfollow up & \\
\hline I & $17(29.8 \%)$ \\
\hline II & $14(24.6 \%)$ \\
\hline III & $11(19.3 \%)$ \\
\hline IV & $13(22.8 \%)$ \\
\hline V & $2(3.5 \%)$ \\
\hline 3 months follow up & \\
\hline I & $19(33.3 \%)$ \\
\hline II & $19(33.3 \%)$ \\
\hline III & $9(15.8 \%)$ \\
\hline IV & $10(17.5 \%)$ \\
\hline V & \\
\hline I months follow up & \\
\hline & \\
\hline & \\
\hline & \\
\hline & \\
\hline & \\
\hline
\end{tabular}

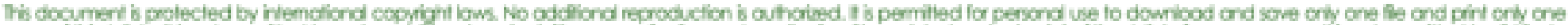

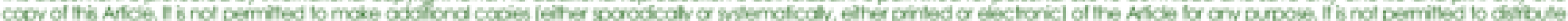

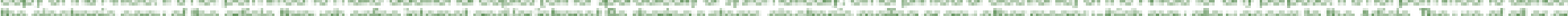

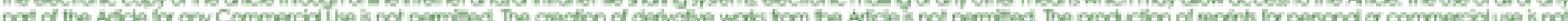

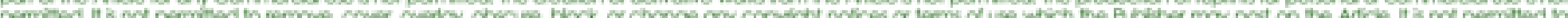

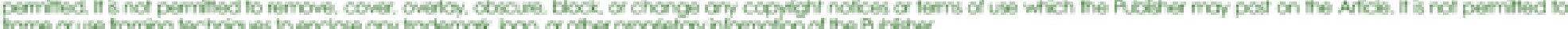

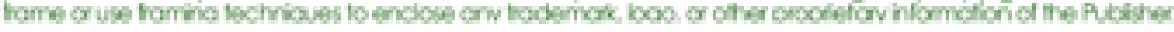




\begin{tabular}{|l|c|}
\hline II & $17(29.8 \%)$ \\
\hline III & $5(8.8 \%)$ \\
\hline IV & $9(15.8 \%)$ \\
\hline V & 0 \\
\hline
\end{tabular}

Table 4 Clinical follow-up: Modified McCormick scale grade

\begin{tabular}{|c|c|c|c|c|}
\hline & $\begin{array}{c}\text { Multimodal } \\
\text { IONM } \\
\text { (SSEP+MEP+ } \\
\text { D-Wave) }\end{array}$ & SSEP & MEP & D-Wave \\
\hline Truenegative & 44 & 29 & 27 & 43 \\
\hline Truepositive & 7 & 2 & 6 & $7 *$ \\
\hline Falsenegative & 0 & 5 & 1 & 0 \\
\hline Falsepositive & 2 & 17 & 19 & 3 \\
\hline Sensitivity & $100 \%$ & $28,6 \%$ & $85,71 \%$ & $100 \%$ \\
\hline Specificity & $95,65 \%$ & $63 \%$ & $58,7 \%$ & $93,48 \%$ \\
\hline $\begin{array}{c}\text { Positivepredictive } \\
\text { value }\end{array}$ & $77,7 \%$ & $11,1 \%$ & $24 \%$ & $70 \%$ \\
\hline $\begin{array}{c}\text { Negativepredictive } \\
\text { value }\end{array}$ & $100 \%$ & $85,71 \%$ & $96,4 \%$ & $100 \%$ \\
\hline Likelihoodratio+ & 23 & 1,13 & 2,08 & 15,33 \\
\hline Likelihoodratio- & 0 & 0,77 & 0,24 & 0 \\
\hline AUC & 0.978 & 0.542 & 0.722 & 0.967 \\
\hline 95\%Cl & $0.894-0.997$ & $0,399-0,68$ & $0,5820-0.836$ & $0.878-0.996$ \\
\hline PValue & $\mathbf{0 . 0 0 0 1}$ & 0.71 & 0.002 & $\mathbf{0 . 0 0 0 1}$ \\
\hline
\end{tabular}

Table 5 Sensitivity, specificity, positive predictive value (PPV), negative predictive value (NPV), like ihood rdio positive ( $\mathrm{LH}+$ ) and like ihood rdio negative ( $\mathrm{LH}-$-), area under thecurve (AUC) and stastical analysis of IONM.

Four patients without D-wave recording havenot been induded in the statistical analysis.

* Patients with postoperdive permenent motor deficit and D-wave amplitude reduced of $50 \%$ or more 


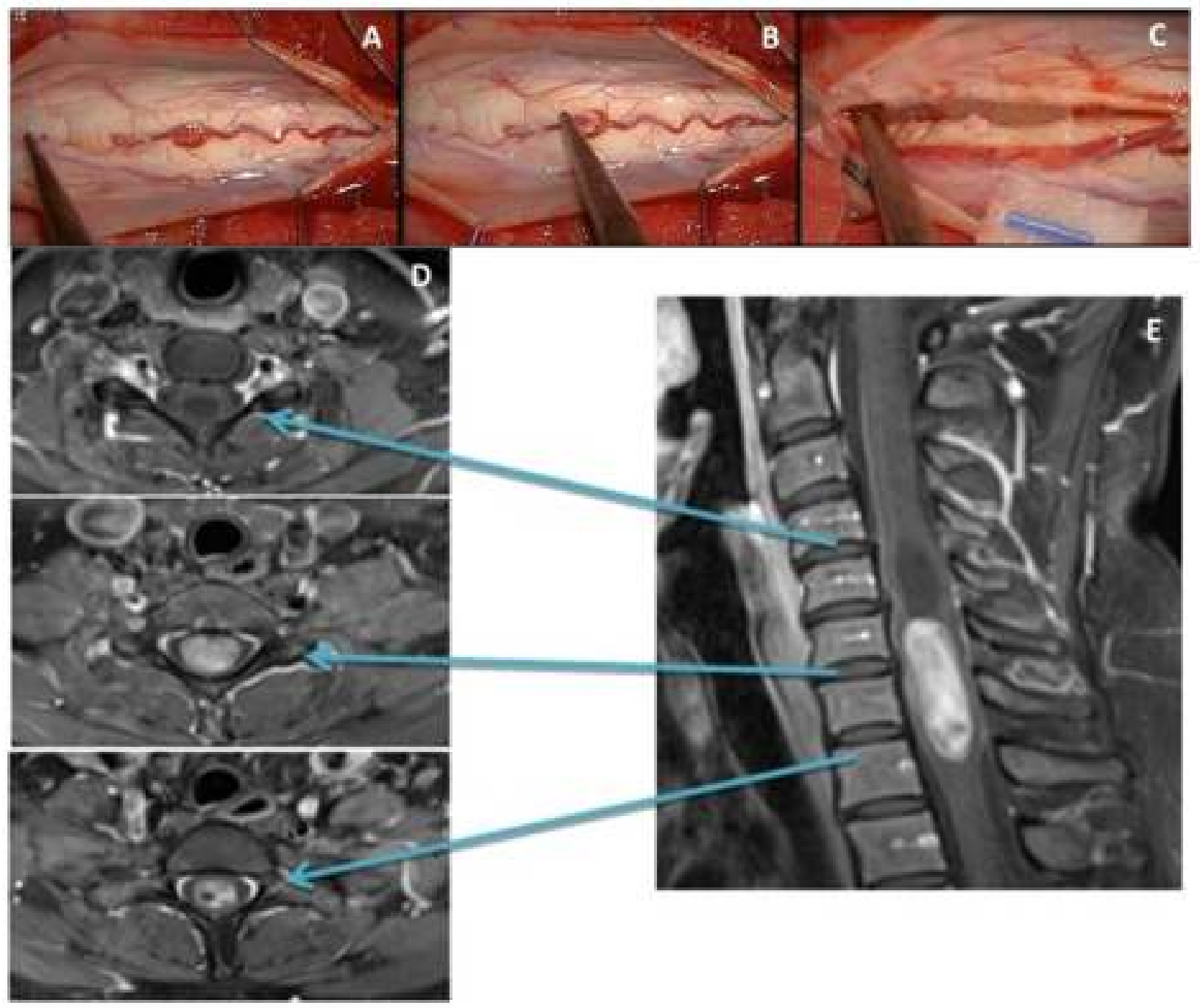

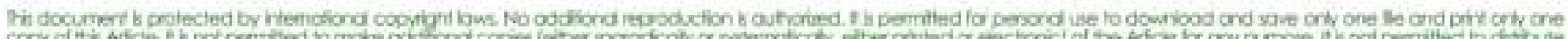

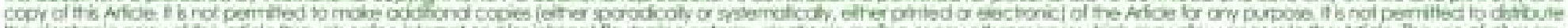

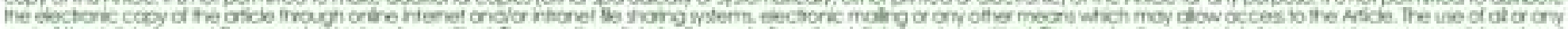

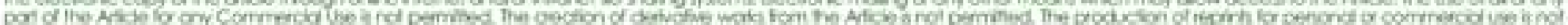

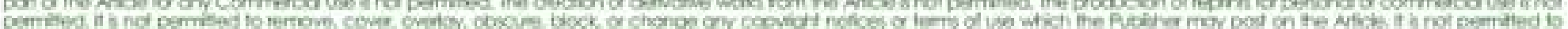

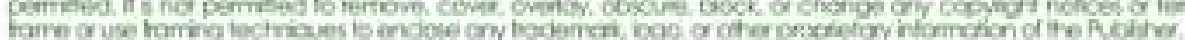




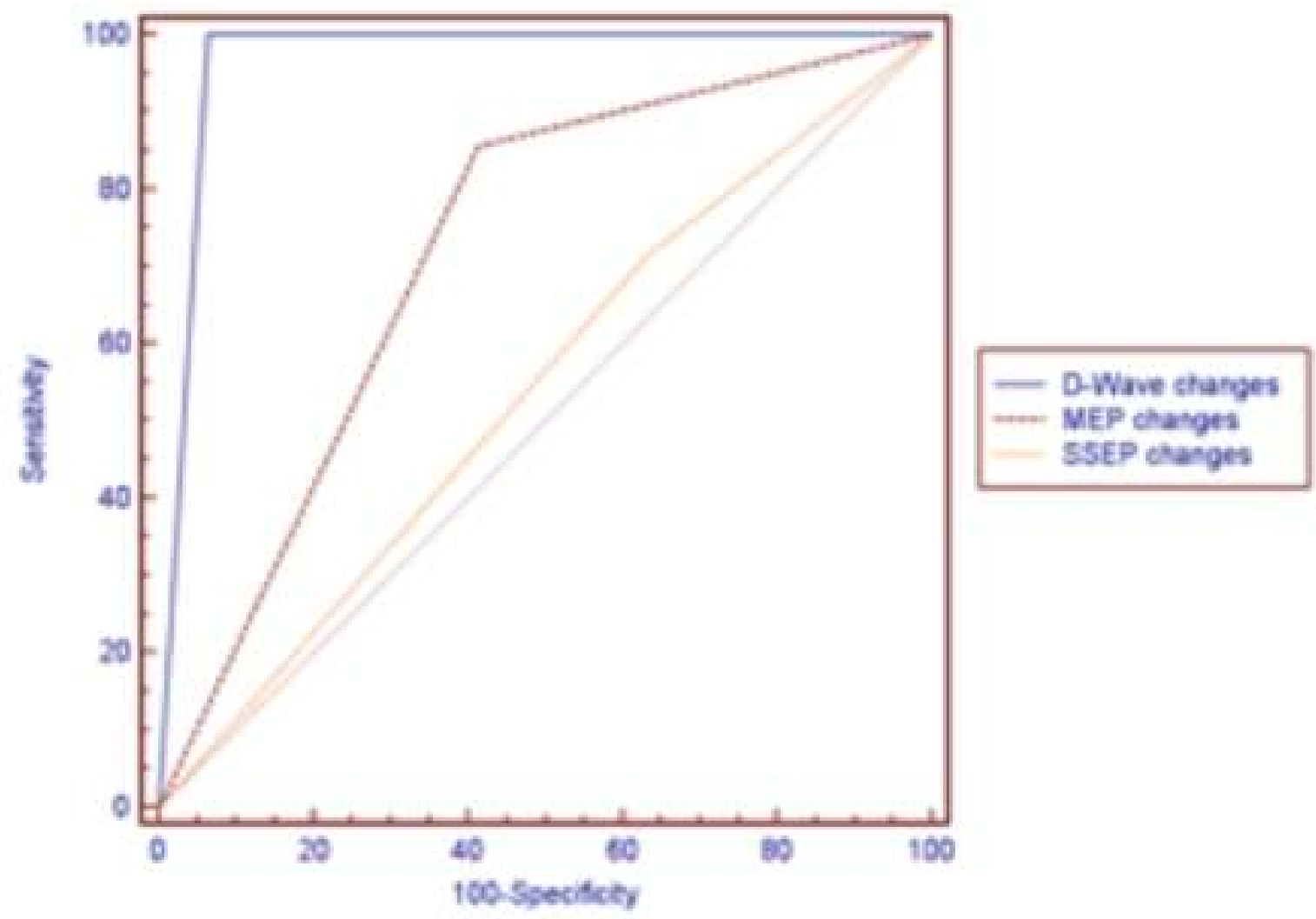

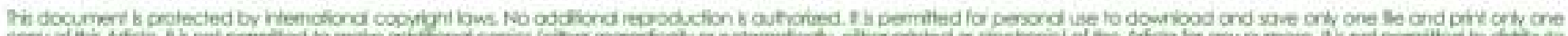

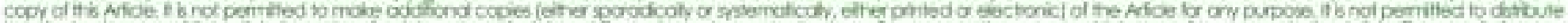

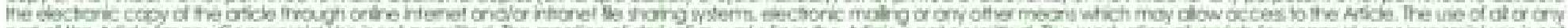

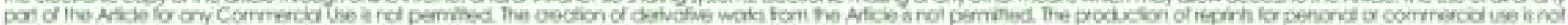

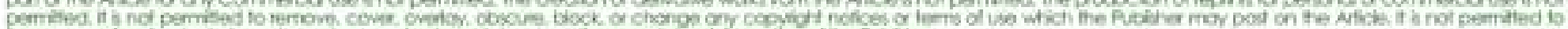

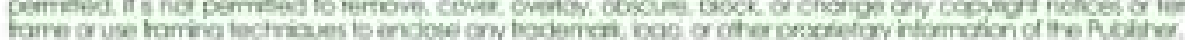

